\title{
Validating the growth increment periodicity in the otoliths of three small progenetic gobies
}

\author{
Sílvia Pérez-Mayol ${ }^{1}$, Itziar Álvarez ${ }^{1}$, Inmmaculada Riera-Batle ${ }^{2}$, Amalia Grau ${ }^{1,3,4}$, \\ Beatriz Morales-Nin ${ }^{1}$ \\ ${ }^{1}$ Institut Mediterrani d'Estudis Avançats (IMEDEA), CSIC/UIB, Miquel Marquès 21, 07190 Esporles, Balearic Islands, Spain. \\ (SP-M) (Corresponding author). E-mail: silvia@imedea.uib-csic.es. ORCID iD: https://orcid.org/0000-0003-3974-7657 \\ (IA) E-mail: itziar@imedea.uib-csic.es. ORCID iD: https://orcid.org/0000-0003-4128-9149 \\ (AG) E-mail: amaliagrau@dgpesca.caib.es. ORCID iD: https://orcid.org/0000-0002-6461-6985 \\ (BM-N) E-mail: beatriz@imedea.uib-csic.es. ORCID iD: https://orcid.org/0000-0002-7264-0918 \\ ${ }^{2}$ Direcció General de Pesca i Medi Marí, Balearic Government, Palma, Balearic Islands, Spain. \\ (IR) E-mail: miriera@ dgpesca.caib.es. ORCID iD: https://orcid.org/0000-0002-3969-1641 \\ ${ }^{3}$ Laboratori d'Investigacions Marines i Aqüicultura (LIMIA), Balearic Government, Av. Gabriel Roca 69. \\ 07158 Port d'Andratx, Balearic Islands, Spain. \\ ${ }^{4}$ Instituto de Investigaciones Agroambientales y de Economía del Agua (INAGEA) (INIA-CAIBUIB), \\ Ctra. Valldemossa km 7.5, Ed Guillem Colom Casasnoves, 07122 Palma de Mallorca, Balearic Islands, Spain.
}

\begin{abstract}
Summary: We determined the efficacy of marking the otoliths of three small-sized progenetic gobies to validate their increment periodicity. These small gobies have high mortalities and rearing difficulties, making direct validation difficult. The otoliths were marked by immersing the fish in a bath of alizarin red S. The fishes were euthanatized and the number of increments in their otoliths laid down after the fluorescent mark were counted and compared with the number of elapsed days. The results validated the daily periodicity of Aphia minuta and Pseudaphya ferreri. The high mortality hindered the validation of Crystallogobius linearis.
\end{abstract}

Keywords: age; mortality; rearing; Aphia minuta; Pseudaphya ferreri; Crystallogobius linearis.

Validando la periodicidad de los incrementos de crecimiento en los otolitos de tres pequeños góbidos progenéticos

Resumen: Se determinó la eficacia en el marcado de los otolitos de tres góbidos progenéticos de pequeña talla con el fin de validar la periodicidad en la deposición de los incrementos de crecimiento. Estos pequeños góbidos presentan altas mortalidades y dificultades en su cría, por lo que la validación directa de su crecimiento es difícil. Los otolitos fueron marcados con rojo de alizarina S (ALR). Los peces fueron eutanasiados y el número de incrementos depositados después del marcaje con el colorante fluorescente se contó y comparó con el número de días transcurridos. Los resultados obtenidos validaron la periodicidad diaria para Aphia minuta y Pseudaphya ferreri. La elevada mortalidad impidió la validación en Crystallogobius linearis.

Palabras clave: edad; mortalidad, cría; Aphia minuta; Pseudaphya ferreri; Crystallogobius linearis.

Citation/Como citar este artículo: Pérez-Mayol S., Álvarez I., Riera-Batle I., Grau A., Morales-Nin B. 2021. Validating the growth increment periodicity in the otoliths of three small progenetic gfobies. Sci. Mar. 85(3): 169-173. https://doi. org/10.3989/scimar.05162.015

Editor: V.M. Tuset.

Received: January 8, 2021. Accepted: April 9, 2021. Published: August 13, 2021.

Copyright: (C) 2021 CSIC. This is an open-access article distributed under the terms of the Creative Commons Attribution 4.0 International (CC BY 4.0) License.

\section{INTRODUCTION}

Three small-sized pelagic neritic gobies are the target species of a valuable small-scale fishery which has developed particularly in the western and central Mediterranean. The target species are transparent goby Aphia minuta (Risso, 1810) and Ferrer's goby Pseu- daphya ferreri (De Buen and Fage, 1908), and the bycatch species is crystal goby Crystallogobius linearis (von Düben, 1845). This traditional seasonal fishery uses a special purse-seine net over sand and gravel bottoms inside bays of Majorca (Balearic Islands) (Iglesias and Martorell 1992, Iglesias et al. 1994). Similar fisheries are carried out in Spain off Murcia (Martín- 
ez-Baño et al. 1993), in the Ligurian Sea (Relini-Orsi and Fanciulli 1977, Relini et al. 1996), in the northern Tyrrhenian Sea (Serena et al. 1990, Baino et al. 1996) and in the Adriatic Sea (Froglia and Gramitto 1989, Ungaro et al. 1994). In the western Mediterranean, the commercial exploitation takes place during one fishing season each year, generally from December to March, in concomitance with coastal migration and shoaling of transparent goby in winter (Morales-Nin et al. 2017).

The three species share morphological and evolutive traits (Kon and Yoshino 2002), being small progenetic pelagic species ( $<60 \mathrm{~mm}$ total length) which live no more than one year (De Buén 1931). A. minuta and $P$. ferreri gobies are distributed in the European Atlantic from Gibraltar to the coasts of Norway and the Baltic Sea, and in the Mediterranean (Miller 1986, La Mesa et al. 2005), whereas C. linearis is restricted to the Mediterranean (Wheeler 1992). The life history traits of $A$. minuta have been studied in the Mediterranean, including reproductive biology (Caputo et al. 2001, 2003, Giovannotti et al. 2007), age and growth (Iglesias et al. 1997, La Mesa 1999), life cycle (Iglesias and Morales-Nin 2001) and population structure (Giovannotti et al. 2009, Ruggeri et al. 2016). C. linearis reproduction (Caputo et al. 2003) and age and growth (La Mesa 2001) have been determined. No data are available for $P$. ferreri.

The A. minuta population is composed of two cohorts, one born in summer and one in winter (Iglesias and Morales-Nin 2001), while C. linearis has a long spawning period of eight months (La Mesa 2001). The short life span, low fecundity and high mortality rate of these species make them particularly vulnerable to fishing pressure. The state of the stocks in Catalonia and Majorca (western Mediterranean) seems stable for $A$. minuta, shows a decline for $C$. linearis and no estimates are available for P. ferreri (STECF 2018). In Majorca (Balearic Islands) the captures of these species show inter-annual and seasonal fluctuations that have consequences on the productivity of the fishery. Therefore, it is necessary to improve the knowledge of these species and contribute to the management of the fishery. Owing to their short life span, age can be determined by daily growth increments (DGI) in the otoliths (Iglesias and Morales-Nin 2001). Iglesias et al. (1997) validated the periodicity of DGI of transparent goby by marking them with $\mathrm{SrCl}_{2}$ in captivity, a technique that requires the use of scanning electron microscopy to detect the mark. No validation has been carried out for the other species. The aim of the present study was threefold: to test the feasibility of a fluorescent marker for marking the otoliths; to validate the daily periodicity of the increments in the otoliths of the three species; and to try to rear $C$. linearis and $P$. ferreri in captivity for the first time.

\section{MATERIALS AND METHODS}

To carry out the study, fish were collected from hauls of the commercial small-scale fishery under normal fishing boat operations conducted during the winter seasons of 2014 and 2015. For transport to the Balearic Government aquaculture facilities of the Laboratori d'Investigacions Marines i Aqüicultura (LIMIA), the fish were kept in a $50 \mathrm{~L}$ container without water renewal but equipped with aeration, maintaining the $\mathrm{O}_{2}$ level above $7 \mathrm{mg} \mathrm{L}^{-1}$. The duration of the transport never exceeded $2 \mathrm{~h}$. The sampling, survival and experimental protocols are detailed in Table 1.

The first (A. minuta) fishes were captured in February 2014 at $30 \mathrm{~m}$ depth and a water temperature of $13.5^{\circ} \mathrm{C}$. Fifty to sixty individuals were placed in a set of three $90 \mathrm{~L}$ aquaria with open seawater flow, constant aeration and at room temperature (ranging from $14.5^{\circ} \mathrm{C}$ to $18.5^{\circ} \mathrm{C}$ during the experimental period). On the following day, they were fed with fresh Artemia (nauplius and metanauplius) enriched with fatty acids and vitamins, and frozen copepoda, krill, mysidacea

Table 1. - Experimental procedures, survival after capture and marking, mean length and weight of the fishes and otolith growth relationships. Only data of surviving fishes and repeated readings with a coefficient of variation of less than $10 \%$ were considered. SD, standard deviation. SL, survival at landing; SW, survival at 1st week; S1, survival to 1st marking; S2, survival to 2nd marking; TL, fish mean total length; W, fish mean weight; $\mathrm{N}$, number of otoliths examined; D1, mean distance from the 1 st mark to the otolith edge; D2, mean distance from the 2 nd mark to the otolith edge; R1, relationship between observed $(\mathrm{O})$ and expected (E) number of daily growth increments (in days) for the 1st mark; R2, relationship between observed $(\mathrm{O})$ and expected $(\mathrm{E})$ number of daily growth increments (in days) for the 2 nd mark

\begin{tabular}{|c|c|c|c|c|c|c|c|c|c|c|c|c|c|c|}
\hline Species & $\begin{array}{l}\text { Date of } \\
\text { capture }\end{array}$ & $\begin{array}{l}\text { SL } \\
(\%)\end{array}$ & $\begin{array}{l}\text { SW } \\
(\%)\end{array}$ & $\begin{array}{c}\text { Date of } 1^{\text {st }} \\
\text { marking }\end{array}$ & $\begin{array}{c}\text { S1 } \\
(\%)\end{array}$ & $\begin{array}{l}\text { Date of } 2^{\text {nd }} \\
\text { marking }\end{array}$ & $\begin{array}{l}\mathrm{S} 2 \\
(\%)\end{array}$ & $\begin{array}{c}\mathrm{TL} \\
( \pm \mathrm{SD}) \\
(\mathrm{mm})\end{array}$ & $\begin{array}{c}\mathrm{W} \\
( \pm \mathrm{SD}) \\
(\mathrm{g})\end{array}$ & $\begin{array}{c}\mathrm{N} \\
\text { (retained) }\end{array}$ & $\begin{array}{c}\text { D1 } \\
( \pm \mathrm{SD}) \\
(\mu \mathrm{m})\end{array}$ & $\begin{array}{c}\mathrm{D} 2 \\
( \pm \mathrm{SD}) \\
(\mu \mathrm{m})\end{array}$ & R1 & $\mathrm{R} 2$ \\
\hline Aphia minuta & $\begin{array}{l}07 / 02 / 2014 \\
12 / 02 / 2014\end{array}$ & 57.14 & 62 & $20 / 02 / 2014$ & 100 & $12 / 03 / 2014$ & 100 & $\begin{array}{c}36.83 \\
( \pm 3.32)\end{array}$ & $\begin{array}{c}0.261 \\
( \pm 0.062)\end{array}$ & $42(35)$ & $\begin{array}{c}63.31 \\
( \pm 28.87)\end{array}$ & $\begin{array}{c}38.47 \\
( \pm 18.64)\end{array}$ & $\begin{array}{c}\mathrm{O}= \\
0.996 \mathrm{E} \\
\mathrm{R}^{2}= \\
0.95\end{array}$ & $\begin{array}{c}\mathrm{O}= \\
0.944 \mathrm{E} \\
\mathrm{R}^{2}= \\
0.94\end{array}$ \\
\hline $\begin{array}{l}\text { Pseudaphya } \\
\text { ferreri }\end{array}$ & $24 / 04 / 2015$ & 42.81 & 17 & $28 / 04 / 2015$ & 100 & - & - & $\begin{array}{c}31.26 \\
( \pm 1.95)\end{array}$ & $\begin{array}{c}0.213 \\
( \pm 0.045)\end{array}$ & $24(13)$ & $\begin{array}{c}63.69 \\
( \pm 42.18)\end{array}$ & - & $\begin{array}{c}\mathrm{O}= \\
1.246 \mathrm{E} \\
\mathrm{R}^{2}= \\
0.93\end{array}$ & - \\
\hline $\begin{array}{l}\text { Crystallogobius } \\
\text { linearis }\end{array}$ & $24 / 04 / 2015$ & 14.07 & 13 & $28 / 04 / 2015$ & 90 & - & & $\begin{array}{c}25.97 \\
( \pm 1.30)\end{array}$ & $\begin{array}{c}0.053 \\
( \pm 0.011)\end{array}$ & $14(3)$ & $\begin{array}{c}7.371 \\
( \pm 2.08)\end{array}$ & - & $\begin{array}{c}\mathrm{O}= \\
0.708 \mathrm{E} \\
\mathrm{R}^{2}= \\
0.93\end{array}$ & - \\
\hline
\end{tabular}



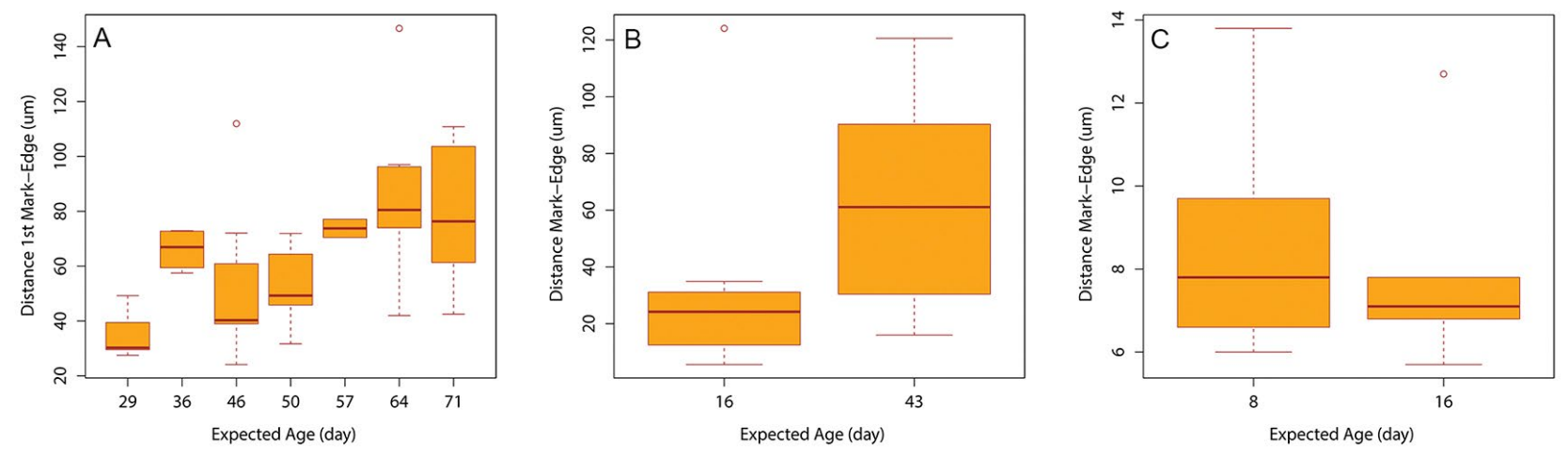

Fig. 1. - Box-plots showing the relationship between the otolith growth (as distance from the ALZ mark to the edge) and the expected age. A, A. minuta; B, P. ferreri; C, C. linearis.

and adult artemia. After one week, the fish were acclimatized to the environment and were responding favourably to the diet. On 20 February, a total of 159 A. minuta were marked by immersion in the fluorescent marker alizarin red S (ALR) at a concentration of $65 \mathrm{mg} \mathrm{L}^{-1}$ for $23 \mathrm{~h}$ (Taylor et al. 2005). A second marking was performed 20 days after the first one. Beginning at the first marking, periodic sacrifices of 10 fishes were performed at $\sim 8$-day intervals until the end of the experimental period (71 days from the first marking). As the captures of both $P$. ferreri and $C$. linearis were very low in 2014, a second set of experiments was performed for these two species in 2015. Fish were captured in April 2015 at $37 \mathrm{~m}$ depth and a water temperature of $15.2^{\circ} \mathrm{C}$. After acclimatization and rearing conditions as above, $56 C$. linearis and 67 P. ferreri were marked with ALR and sequentially sacrificed 16 and 43 days from marking, respectively $\left(18.0^{\circ} \mathrm{C}\right.$ to $23.5^{\circ} \mathrm{C}$ during the experimental period). The end of each experiment was set in concomitance with the increase in daily mortality (Table 1). The fishes were sacrificed with an overdose of tricaine metanosulphonate according to animal welfare procedures approved by Spanish law (RD53/2013).

The sacrificed fishes were measured with an electronic profile projector (Mitutoyo PJ-A3000) and weighed to the nearest $\mathrm{mg}$, and the otoliths were extracted following standard procedures. A total of 94 otoliths of $A$. minuta, 43 of $C$. linearis (corresponding to dead and sacrificed individuals) and 28 of $P$. ferreri were extracted and processed. The left otolith was sanded and polished for examination under a microscope. Digital images (200x and 400x) were obtained with both brightfield and UV lights to visualize the increments and the ALR marks, respectively. DGI laid down between marks and to the otolith edge were enumerated using the ObjectJ plug-in of the Image J free software. In addition, the distances between marks and to the otolith edge were determined (Fig. 1). All otoliths were read at least twice and repeated readings with a coefficient of variation over $10 \%$ were not considered. The observed (read) and expected (days) number of increments were plotted, and daily periodicity was assumed if the slope of the regression was not significantly different from 1 (Fig. 2).
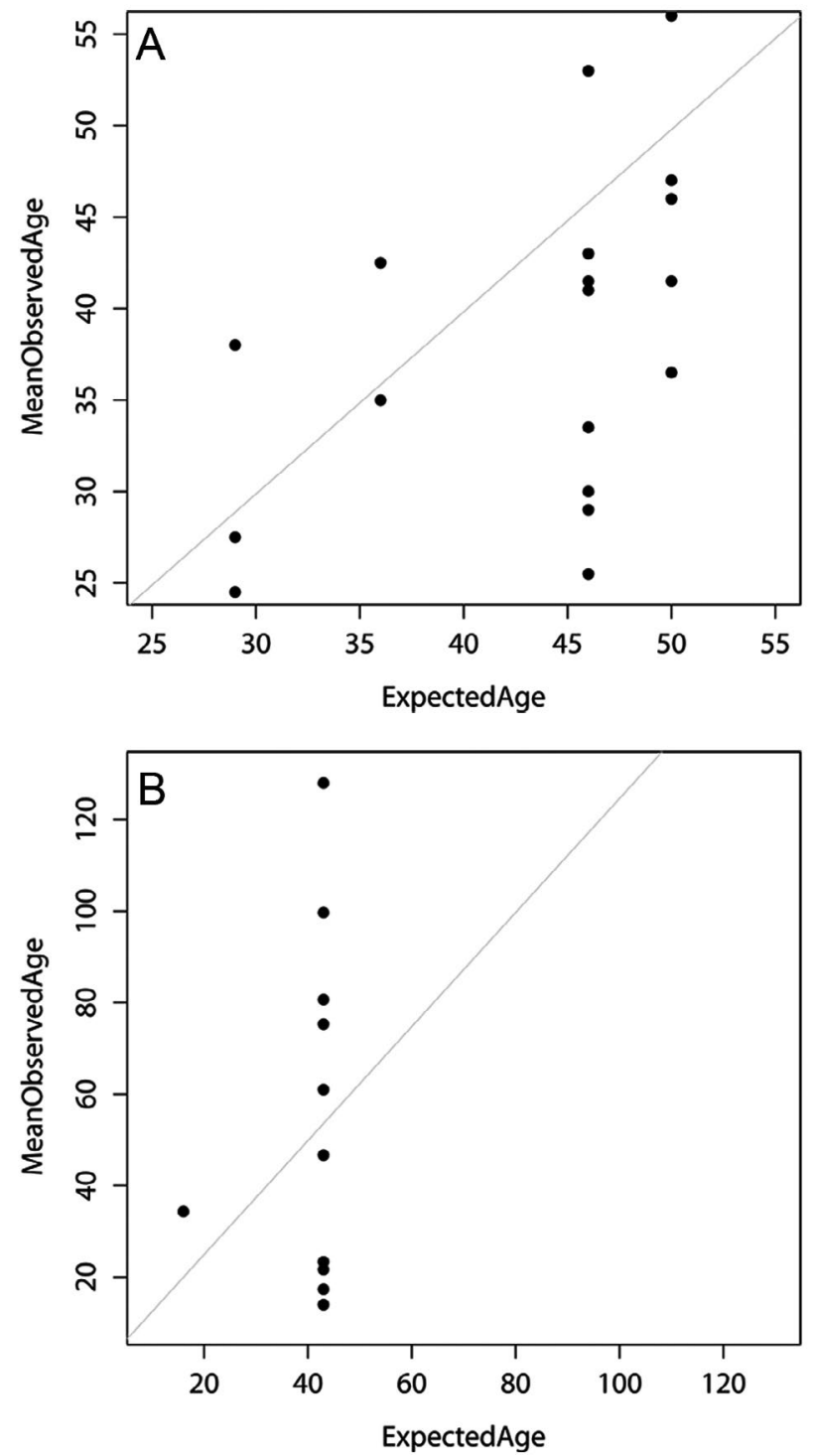

Fig. 2. - Relationship of the mean number of daily growth increments laid down after marking (two observations) and the expected (elapsed) days for A. minuta (A) and P. ferreri (B). Grey line represents slope relationship. Note that for $P$. ferreri several mean observations are coincident (in 23 and 46 observed days) and black dots are overlapped. 


\section{RESULTS AND DISCUSSION}

Survival rate at landing varied between species, being higher for A. minuta (57.14\%), medium for P. ferreri (42.81\%) and lower for C. linearis (14.07\%). According to our results (Table 1), these progenetic gobies are very sensitive to handling caused by fishing and experimental acclimatization, and $C$. linearis is the most sensitive. Depth and temperature at fishing seem to be the most important environmental drivers in the survival of target species of the transparent goby fishery (Gil et al. 2020). Injuries produced by changes in pressure (barotrauma) and temperature shock, especially at temperate and tropical latitudes, have been reported to affect survival of fishes subjected to fisheries activities (Giomi et al. 2008, Curtis et al. 2015, Gil et al. 2020). Survival at landing and after the first week seems to be affected by these drivers. Furthermore, gobies showed poor acclimatization to captive rearing conditions, especially $C$. linearis which exhibited the worst adaptation (Table 1). The accumulated effects of barotrauma, temperature shock, trauma related to handling and poor adaptation to diet (more typical for larvae than for adult gobies) could be factors explaining the delaying mortality observed during the maintenance period in captivity, as in other laboratory discard experiments (Davis 2002). C. linearis was the most sensitive to experimental conditions, with high mortality rates during the experimental period $(66.07 \%$ in only 20 days), which forced its duration to be shortened. Mortality in A. minuta was $59.12 \%$ in 71 days and mortality in P. ferreri was $58.21 \%$ in 43 days. No mortalities associated with marking were detected, except very few cases of $C$. linearis (Table 1). As these species are very sensitive to water temperature, the differences in the temperature between the two experimental periods could have caused the lower survival in the 2015 experiments. Owing to the poor conditions of $C$. linearis, only the otoliths of sacrificed fishes were retained.

All the otoliths had a fluorescent mark that could be observed under the microscope and they all showed growth after the mark was laid down (Table 1), but growth rate showed high intra-individual variability in all species (Fig. 1). In the case of A. minuta, the ALR mark was observed with more clarity on the otolith's ventral edge. A. minuta showed a better otolith growth and definition in the growth increments, with $83.3 \%$ of the readings under the coefficient of variation limit (Table 1, retained otoliths). P. ferreri showed good otolith growth in distance between mark and edge and a multi-ring pattern per day. The presence of sub-units caused $45.8 \%$ of the readings to be rejected. $C$. linearis individuals that reached the end of the experiment showed much lower otolith growth (Fig. 1C) and increment clarity; only $21.4 \%$ of the repeated otolith readings had a coefficient of variation lower than $10 \%$ and just three otoliths were retained.

The mean increment width determined from the growth after the mark and the number of elapsed days showed a mean increment thickness beyond the limit of the microscope resolution (0.7-1.2 $\mu \mathrm{m})$. Therefore, the relatively low reproducibility of the readings might be due to low increment definition and the presence of sub-daily increments caused by unfavourable rearing conditions. Iglesias et al. (1997) also found a low clarity of the increments in the case of A. minuta, with only $18 \%$ of the marked otoliths showing a clear increment pattern. For all the species, the relationship between the observed and expected days that elapsed between the marking events and the sacrifices was validated, showing correlations of between 0.93 and 0.95 when the intercept was forced to 0 (Table 1). Regression slopes were 0.94 and 1.25 for $A$. minuta and P. ferreri, respectively (Fig. 2). However, C. linearis adjustment was poorer, with a regression slope distant from 1 (i.e. 0.71). The rearing conditions had probably affected the recent otolith growth after marking considering the elapsed number of days (Fig. 1). The variability increased during the experimental period except in $C$. linearis, probably due to the high mortality it experienced.

Direct validation of the increment periodicity in the otoliths requires for instance keeping in captivity and marking the fish (Panfili and Morales-Nin 2002), though this procedure is not always feasible. We can conclude that these delicate small gobies could be kept in captivity for discrete periods of time under low temperatures and that ALR at the reported concentration was successful in marking $100 \%$ of the otoliths. However, the daily periodicity of the observed increments was only validated for $A$. minuta and $P$. ferreri. Several authors have reported that growth increments are less clear in fishes in captivity than in wild specimens, and in our case the main difficulty was identifying the daily increments. Here we provide an alternative marking technique and directly validate the periodicity of the two main species of the fishery.

\section{ACKNOWLEDGEMENTS}

We thank E. Massuti for his technical assistance and the Laboratori d'investigacions Marines i Aqüicultura (LIMIA) staff for their help in the experimental procedures. We also thank G. Morey and the fishermen who assisted in providing samples. SP's salary was cofunded by the DGPUR of the Balearic Government and the CSIC. This contribution is a result of the "Unidad Asociada IMEDEA-LIMIA".

\section{ETHICS STATEMENT}

The study was authorized by the Fisheries Department of the Balearic Government. All samplings, experimentation and euthanasia of individuals were carried out in strict accordance with the recommendations of Directive 2010/63/EU, transposed to Spanish law (RD 53/2013, BOE n³4 of 8 February 2013). All efforts were made to minimize suffering. 


\section{REFERENCES}

Baino R., Auteri R, Donati L. 1996. Crescita e reclutamento alla pesca del rosseto. Biol. Mar. Medit. 3: 525-526.

Caputo V., Candi G., La Mesa M., et al. 2001. Pattern of gonad maturation and the question of semelparity in the paedomorphic goby Aphia minuta. J. Fish Biol. 58: 656-669. https://doi.org/10.1111/j.1095-8649.2001.tb00520.x

Caputo V., Mesa M.L., Candi G., et al. 2003. The reproductive biology of the crystal goby with a comparison to that of the transparent goby. J. Fish Biol. 62: 375-385. https://doi.org/10.1046/j.1095-8649.2003.00031.x

Curtis J.M., Johnson M.W., Diamond S.L., et al. 2015. Quantifying delayed mortality from barotrauma impairment in discarded red snapper using acoustic telemetry. Mar. Coast. Fish. 7: 434-449. https://doi.org/10.1080/19425120.2015.1074968

Davis M.W. 2002. Key principles for understanding fish bycatch discard mortality. Can. J. Fish. Aquat. Sci. 59: 1834-1843. https://doi.org/10.1139/f02-139

De Buén F. 1931. Notas de la familia Gobiidae. Observaciones sobre algunos géneros y sinopsis de especies ibéricas. Notas Resum. Inst. Esp. Oceanogr. 2: 1-76.

Froglia C., Gramitto M.E. 1989. La pesca del rossetto (Aphia minuta) nel medio Adriatico. Nova Thalassia 10: 447-455.

Gil M.M., Palmer M., Morey G., et al. 2020. Assessing relative post-release mortality for the transparent goby fishery: Environmental drivers and the utility of vitality metrics. PloS ONE 15: e0230357. https://doi.org/10.1371/journal.pone.0230357

Giomi F., Raicevich S., Giovanardi O., et al. 2008. Catch me in winter! Seasonal variation in air temperature severely enhances physiological stress and mortality of species subjected to sorting operations and discarded during annual fishing activities. Hydrobiologia 606: 195-202. https://doi.org/10.1007/s10750-008-9336-x

Giovannotti M., Cerioni P.N., La Mesa M., et al. 2007. Molecular phylogeny of the three paedomorphic Mediterranean gobies (Perciformes: Gibiidae). J. Exp. Zool. Part B 308: 722-729. https://doi.org/10.1002/jez.b.21192

Giovannotti M., La Mesa M., Caputo V. 2009. Life style and genetic variation in teleosts: The case of pelagic (Aphia minuta) and benthic (Gobius niger) gobies (Perciformes: Gobiidae). Mar. Biol. 156: 239-252. https://doi.org/10.1007/s00227-008-1078-9

Iglesias M., Martorell J.M. 1992. La pesquería de góbidos en las Islas Baleares. Inf. Tec. Inst. Esp. Oceanogr. 116: 1-18.

Iglesias M., Morales-Nin B. 2001. Life cycle of the pelagic goby Aphia minuta (Pisces: Gobiidae). Sci. Mar. 65: 183- 192. https://doi.org/10.3989/scimar.2001.65n3183

Iglesias M., Massutí E., Reñones O., et al. 1994. Three smallscale fisheries based on the island of Majorca (NW Mediterranean). Boll. Soc. Hist. Nat. Illes Balears 37: 35-58.

Iglesias M., Brothers E.B., Morales-Nin B. 1997. Validation of daily deposition in otoliths. Age and growth determination of Aphia minuta (Pisces: Gobiidae) from the Northwestern Mediterranean. Mar. Biol. 129: 279-287. https://doi.org/10.1007/s002270050168

Kon T., Yoshino T. 2002. Diversity and evolution of life histories of gobioid fishes from the viewpoint of heterochrony. Mar. Freshw. Res. 53: 377- 402.

https://doi.org/10.1071/MF01117
La Mesa M. 1999. Age and growth of Aphia minuta (Pisces: Gobiidae) from the central Adriatic Sea. Sci. Mar. 63: 147-155. https://doi.org/10.3989/scimar.1999.63n2147

La Mesa M. 2001. Age and growth of Crystallogobius linearis (von Düben, 1845) (Teleostei: Gobiidae) from the Adriatic Sea. Sci. Mar. 65: 375-381. https://doi.org/10.3989/scimar.2001.65n4375

La Mesa M., Arneri E., Caputo V., et al. 2005. The transparent goby, Aphia minuta: review of biology and fisheries of a paedomorphic European fish. Rev. Fish Biol. Fisher. 15: 89-109. https://doi.org/10.1007/s11160-005-1613-4

Martínez-Baño P., Vizuete F., Mas J. 1993. The fishery of the transparent goby A. minuta (Risso,1810) on the fishing grounds off Murcia (south-east Spain). Sci. Mar. 57: 199205.

Miller P.J. 1986. Gobiidae. In: Whitehead P.J.P., Bauchot M.-L, Hureau J.C., et al. (eds), Fishes of the North-eastern Atlantic and the Mediterranean. UNESCO, Paris, Vol 3, pp. 10191085. https://doi.org/10.2307/1444931

Morales-Nin B., Grau A.M., Aguilar J.S., et al. 2017. Balearic Islands boat seine fisheries: the transparent goby fishery an example of co-management. ICES J. Mar. Sci. 74: 20532058. https://doi.org/10.1093/icesjms/fsw227

Panfili J., Morales-Nin B. 2002. Semi-direct validation. In: Panfili J., de Pontual H., Troadec H. Wright P.J. (eds), Manual of Fish Sclerochronology. Brest, Ifremer-IRD edition, pp. 129-134.

Relini C., Cima C., Garibaldi F., et al. 1996. Una risorca costiera: il rossetto Aphia minuta mediterranea De Buen, 1931 (Osteichthyes: Gobidae). Biol. Mar. Medit. 3: 205-213.

Relini-Orsi L., Fanciulli G. 1977. First record of Crystallogobius linearis in the Ligurian sea and identification of its young stages as "bianchetti di fondo" (Osteichtyes). Natura 68: $111-122$.

Ruggeri P., Splendiani A., Giovannotti M., et al. 2016. The role of life-history traits, selective pressure and hydrographic boundaries in shaping the genetic structure of the transparent goby, Aphia minuta. Mar. Ecol. 37: 518-531. https://doi.org/10.1111/maec.12266

Scientific, Technical and Economic Committee for Fisheries (STECF). 2018. Assessment of the implementation report of the management plan for boat seines ('sonsera') in the autonomous region of Catalonia (STECF-OWP-18-01). Publications Office of the European Union, Luxembourg, JRC110676.

Serena F., Auteri R., Abella A., et al. 1990. The transparent goby fishery in the northern Thyrrhenian Sea. Rapp. Proc. 32: 257.

Taylor M.D., Fielder D.S., Suthers I.M. 2005. Batch marking of otoliths and fin spines to assess stock enhancement of Argyrosomus japonicus. J. Fish Biol. 66: 1149-1162. https://doi.org/10.1111/j.0022-1112.2005.00678.x

Ungaro N., Casavola N., Marano G., et al. 1994. "Bianchetto" and "Rossetto" fry fisheries in the Manfredonia gulf: effort exerted and catch composition. Oebalia 29: 99-106.

Wheeler A. 1992. A list of the common and scientific names of fishes of the British Isles. J. Fish Biol. 41(Suppl. A): $1-37$.

https://doi.org/10.1111/j.1095-8649.1992.tb05644.x 